\title{
Development of Learning Tools Using the Guided Inquiry Model to Train the Critical Thinking Skills of Islamic Junior High School Students
}

Asy'ari", Rahmat Yunus, Suryajaya

Masters Program of Natural Sciences Teaching, Lambung Mangkurat University, Banjarmasin, Indonesia

\begin{tabular}{ll}
\hline DOI: $10.36348 /$ jaep.2020.v04i11.003 & | Received: $02.11 .2020 \mid$ Accepted: $12.11 .2020 \mid$ Published: 17.11 .2020 \\
*Corresponding author: Asy'ari &
\end{tabular}

Abstract

This study aims to evaluate the practicality, validity, and effectiveness of learning tools for the ecosystem topic in MTs (Islamic Junior High School) students. Learning tools include syllabus, lesson plans, teaching materials, student worksheet, and critical thinking assessment sheets. The research model used is the Tessmer model which includes 1) selfevaluation, 2) expert testing, 3) individual testing, 4) small group testing, and 5) field testing. The data analysis technique used is descriptive quantitative. This type of research data is validity data including content validation of the expert team and students, practicality data, and effectiveness data. This type of research is development research. The research was conducted at MTsN 6 Banjar. The research subjects consisted of the subject of validation of 5 experts, individual trial subjects of 3 students, small group trials consisting of 10 students and field testing consisting of 64 students. The results showed that the learning tools developed were valid, practical and effective. Valid based on the results of the validation of 5 experts who are categorized as very valid. Practical use because the model teacher and students are able to carry out learning activities well and students give good responses. Effective based on: 1) the learning outcomes of students in the experimental class have exceeded classical mastery. 2) Critical thinking skills include formulating problems, providing reasons, grouping, analyzing and formulating conclusions in the experimental class in the good category. The results of the comparison between the experimental class and the control class through the Whitney Test found a significance value below 0.05 indicating that the tools developed and applied to the experimental class were able to train students' critical thinking skills better than the control class. 3) The mastery of the critical thinking skills indicators of students in the experimental class is categorized as good. Individual mastery in the experimental class exceeds the 75\% limit which means that learning mastery has been achieved classically.

Keywords: Development research, learning tools, guided inquiry model, critical thinking skills.

Copyright (C) 2020 The Author(s): This is an open-access article distributed under the terms of the Creative Commons Attribution 4.0 International License (CC BY-NC 4.0) which permits unrestricted use, distribution, and reproduction in any medium for non-commercial use provided the original author and source are credited.

\section{INTRODUCTION}

Science learning is directed to find out and do something so that it can help students to gain a deeper understanding of the natural surroundings. Learning will be more meaningful if learning is associated with the real life of students. Natural science learning basically consists of three components, namely scientific attitudes, scientific processes, and scientific products. This means that science does not only consist of a collection of knowledge or various kinds of facts that are memorized, but science is also an active activity or process of using the mind in studying natural phenomena that cannot be contemplated. Through science learning, students are expected not only to absorb information passively but also to absorb information actively so that the critical thinking skills of students will increase or be trained. Critical thinking skills are needed by students as the nation's successor in facing globalization in line with the development of science and technology. But in fact most of science learning still focuses on low-level cognitive learning outcomes, students are not required to be active in acquiring knowledge in learning. This certainly has an impact on the untrained active students in thinking so that the critical thinking skills of students in Indonesia are still low.

The survey results from PISA and TIMSS also revealed that on average Indonesian students still experience difficulties in answering science questions, especially in critical thinking problems. The National Exam Report clearly describes a declining trend in critical reading competence and understanding in the field of science [1]. The results of interviews with several teachers in $7^{\text {th }}$ grade at MTsN 6 Banjar stated that critical thinking learning has not yet emerged and 
needs intense guidance. The results of their observations indicated that many of their students in $7^{\text {th }}$ grade had not been trained in mastering critical thinking skills in the aspects of formulating problems, providing reasons for classifying, analyzing, and formulating conclusions. The results of the researcher's survey showed that teachers tended to use improvised learning tools. The learning method used by the teacher tends to be one-way learning so that students tend to be passive.

Based on the explanation above, it is necessary to make changes to the learning tools which include syllabus, lesson plans, teaching materials, student worksheets and assessment instruments which are expected to stimulate critical thinking skills of students. The ability of students' critical thinking skills will increase if students have the ability to analyze and solve a problem well. Students who think critically are students who are able to identify, evaluate and construct arguments and are able to solve problems appropriately [1]. Tool development is a process to develop the potential of students in a better direction. There are two important things in the development research that will be carried out, namely: 1) The process of product improvement step by step in producing a prototype; and 2) the main elements that will be produced.

The development of critical thinking skills of students begins with redesigning existing tools with indicators and critical thinking competencies through a guided inquiry model. Guided inquiry model is very suitable for practicing critical thinking skills of students so that it is expected to be able to accommodate changes in learning and thinking in a more critical direction. In addition, the guided inquiry model will also generate a spirit of creativity, provide freedom or autonomous learning, namely to formulate questions and express opinions to students. The use of guided inquiry models is expected to be able to improve students' critical thinking skills. The best learning tool development design refers to the Tessmer development model procedure which includes selfevaluation, expert testing, individual testing, small group testing, and field testing. Starting from the above problems, the researcher feels it is necessary and important to conduct research on the development of learning tools entitled the development of learning materials for energy systems in life using the guided inquiry model to train the critical thinking skills of MTs students.

\section{RESEARCH METHODS}

This type of research is a development research using the Tessmer development design. The Tessmer development design research procedure was carried out in two stages. The first stage is self-evaluation and the second stage is prototyping which consists of an expert review, one to one evaluation, a small group evaluation, and a field test. The research subjects were $7^{\text {th }}$ grade students of MTsN 6 Banjar in the 2019/2020 academic year consisting of 159 students, the classes were taken randomly to be the research sample. Individual trials using a sample of 3 students, small group trials using a sample of 10 students, field trials using class 7D subjects with 32 students as the experimental class and 32 students of the class $7 \mathrm{E}$ as the control class. This research was conducted from September to November 2019 at MTsN 6 Banjar.

Data collection techniques are carried out through observation, documentation, and tests. Observation is used to determine the practicality and effectiveness of the learning tools being developed. Documentation is needed to record the learning process that occurs in accordance with the learning tools developed. The test is used to obtain data on the effectiveness of the learning tools developed on the critical thinking skills of students. The data analysis technique used in this research is descriptive quantitative analysis which includes data analysis on the validity of learning tools, data analysis on the practicality of learning tools, and data analysis on the effectiveness of learning tools.

\section{RESEARCH RESULTS AND DISCUSSION}

The research was conducted in two classes at MTsN 6 Banjar with the same model teacher. The experimental class carried out learning using the guided inkuri approach, while the control class carried out the learning without using the guided inkuri approach (ordinary discussion method). The trial activity aims to produce learning tools that are suitable for use in learning, namely to meet the criteria of practicality and effectiveness. Before being tested, the learning tool is validated by an expert. Validation is carried out to see the contents of the learning tool draft. The assessment also aims to explore comments and suggestions, both in writing and orally by discussing the learning tools developed. Validation was carried out by giving five validators a text of learning tools and validation sheets. Based on the results of the validator's assessment of the product cognitive assessment sheet with five indicators, all of them are categorized as very valid, so that this assessment sheet can be applied to small group trials. Furthermore, the learning tool will be tested on students on a limited basis to explore comments and suggestions about the readability of the developed learning tools.

\section{Practicality of Learning Tools}

The practicality of the learning tools developed refers to the implementation of the learning process in the classroom by measuring teacher activity, student activity assessed by observers and student responses.

\section{Student Response}

The recapitulation of the response results of students in the experimental class and control class can be seen in Table- 1 below. 
Asy'ari et al., J Adv Educ Philos, Nov, 2020; 4(11): 453-457

Table-1: Recapitulation of Student Response Results in $7^{\text {th }}$ Grade MTsN 6 Banjar

\begin{tabular}{|l|l|l|l|l|l|l|}
\hline No & Activity Phase & Teaching Materials & Student Worksheet & Lesson Plan & Mean & Category \\
\hline 1 & Small group & 83.93 & 79.44 & 77.00 & 80.13 & Good (Practical) \\
\hline 2 & $\begin{array}{l}\text { Field Test } \\
\text { (Experiment Class) }\end{array}$ & 78.33 & 78.15 & 72.22 & 76.23 & Good (Practical) \\
\hline 3 & $\begin{array}{l}\text { Field Test } \\
\text { (Control Class) }\end{array}$ & 61.48 & 54.26 & 55.00 & 56.91 & $\begin{array}{l}\text { Not good } \\
\text { (not practical) }\end{array}$ \\
\hline
\end{tabular}

Based on Table-1, we can see that the response of students in the experimental class shows an average score of 76.23 in the good category. This shows that the learning tools developed get a good response from students. This is inversely proportional to the response of students to learning tools that are not developed in the control class which shows an average score of 56.91 in the unfavorable category. This shows that students respond poorly to learning tools that only use the usual discussion method. Good student responses can be used as an indication that the guided inquiry model is able to foster students' learning motivation. As stated by Anam [3] which states that the response of students must be interpreted as an indication that the learning process includes a learning atmosphere, approaches, methods, and learning techniques used can foster students' learning motivation so that they can achieve maximum learning outcomes.

\section{Teacher Activity}

A recapitulation of the results of teacher activity in the experimental class and control class can be seen in Table- 2 below.

Table-2: Recapitulation of MTsN 6 Banjar Teacher Activity Results

\begin{tabular}{|l|l|l|l|l|l|l|l|l|}
\hline No & Activity Phase & \multicolumn{2}{|l|}{ Activity } & \multicolumn{2}{l|}{ Implementation } & \multicolumn{2}{l|}{ Practicality } \\
\cline { 3 - 9 } & & Opening & Main & Closing & Mean & Category & Score & Category \\
\hline 1 & Small group & 3.29 & 3.62 & 3.22 & 3.38 & Good & 84.44 & Practical \\
\hline 2 & Field Test (Experiment Class) & 3.54 & 3.69 & 3.39 & 3.38 & Good & 83.80 & Practical \\
\hline 3 & Field Test (Control Class) & 3.08 & 3.55 & 3.00 & 3.21 & Good & 80.26 & Practical \\
\hline
\end{tabular}

Based on Table-2, we can see that the experimental class shows that the teacher's activity is in the practical category with an average score of 83.80. This shows that the tools developed can be implemented by teachers well. The research results in the control class also showed that the teacher's activity had an average score of 80.26 in the practical category, although it had a lower score than the experimental class. This shows that the tool without development can be implemented by the teacher well. It is in line with Sari's research [4] which states that practical guided inquiry learning tools are learning tools that teachers can do well. Likewise with Singh [5] which states that the teacher is the center of attention in the classroom who empowers class management, so that the practicality of learning can be seen from the teacher's ability to carry out learning.

\section{Student Activities}

The recapitulation of the results of the activities of students in the experimental class and control class can be seen in Table-3 below.

Table-3: Recapitulation of Student Activity Results in $7^{\text {th }}$ Grade MTsN 6 Banjar

\begin{tabular}{|l|l|l|l|l|l|l|l|l|}
\hline No & Activity Phase & \multicolumn{2}{|l|}{ Activity } & \multicolumn{2}{l|}{ Implementation } & \multicolumn{2}{l|}{ Practicality } \\
\cline { 3 - 9 } & & Opening & Main & Closing & Mean & Category & Score & Category \\
\hline 1 & Small group & 3.47 & 3.33 & 3.88 & 3.56 & Good & 88.96 & Very Practical \\
\hline 2 & Field Test (Experiment Class) & 3.63 & 3.5 & 3.88 & 3.67 & Good & 91.75 & Very Practical \\
\hline 3 & Field Test (Control Class) & 3.37 & 3.17 & 3.67 & 3.4 & Good & 85.03 & Very Practical \\
\hline
\end{tabular}

The results of the experimental class research that we can see in Table-3 show that the activities of students are in the very practical category with an average score of 91.75 . This shows that the learning tools developed can be followed by students very well. Likewise with the control class which shows that the activity of students has an average score of 85.03 in the very practical category, although it is still lower than the experimental class. This also shows that learning tools without development can be followed by students very well.

\section{The Effectiveness of Learning Tools}

The effectiveness of learning tools in this study is determined based on the critical thinking skills of students at the end of learning through tests. The 7th grade science subject at MTsN 6 Banjar has a KKM (Minimum Mastery Criteria) limit of $\geq 75$ and a classical completeness limit of $\geq 75 \%$, which means that at least $75 \%$ of students who complete a score of $\geq 75$. A recapitulation of the learning outcomes of students in the experimental class and control class can be seen in pasa Table-4 follows. 
Asy'ari et al., J Adv Educ Philos, Nov, 2020; 4(11): 453-457

Table-4: Recapitulation of Learning Outcomes in $7^{\text {th }}$ Grade MTsN 6 Banjar

\begin{tabular}{|l|l|l|l|l|}
\hline No & Aspect & Small group (\%) & Field Test/Experiment Class (\%) & Field Test/Control Class (\%) \\
\hline 1 & Formulate problems & 70.33 & 69.04 & 67.71 \\
\hline 2 & Giving Reasons & 76.61 & 75.75 & 71.30 \\
\hline 3 & Grouping & 95.56 & 90.28 & 82.12 \\
\hline 4 & Analyze & 69.46 & 73.79 & 58.34 \\
\hline 5 & Conclusion & 90.10 & 84.74 & 68.70 \\
\hline 6 & Average KBK Indicators & 80.41 & 78.72 & 69.63 \\
\hline
\end{tabular}

Based on Table-4, we can see that the experimental class shows that the overall learning outcomes of students on the aspects of critical thinking skills are in the good category with an average score of $78.72 \%$. This shows that the ability of students in 5 (five) aspects of critical thinking skills is good as evidence that the tools developed are effective to improve students' critical thinking skills. In contrast to the critical thinking skills of students in the control class which shows an average value of $69.63 \%$ with sufficient category. This shows that the ability of students in solving questions related to 5 (five) aspects of critical thinking is quite good (quite effective). As for the improvement of students' critical thinking skills in every aspect we can see in Figure 1 for the experimental class and Figure-2 for the control class as follows.

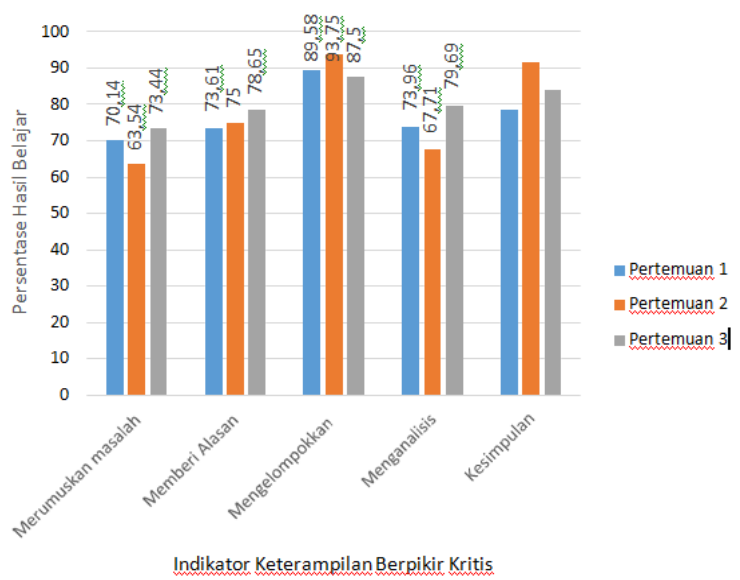

Fig-1: Percentage Diagram of Learning Outcomes for Experimental Critical Thinking Skills

Figure-1 shows an increase in aspects giving reasons. This shows that students have begun to be trained and accustomed to solving problems related to the aspect of giving reasons. In contrast to the aspects of formulating problems, classifying, analyzing and concluding those that have fluctuated. This happens because students are still adapting in translating and solving problems that train critical thinking skills. The aspect of formulating problems in the experimental class showed an increase in the third meeting, this happened because guided inquiry was able to stimulate students' curiosity. As research conducted by Ketpichainarong, Panijpan \& Ruenwongsa [6] that guided inquiry learning is more constructive, giving students the opportunity to ask questions and share learning experiences, as well as increase students' knowledge and develop critical thinking skills. How far the thinking skills and students' understanding of learning content can be seen from the quality of the questions they ask [7].

The completeness of the learning outcomes of students in the experimental class on aspects of critical thinking skills got an average score of $81.25 \%$ in the classical complete learning category, this indicates that guided inquiry learning models that train aspects of 5 (five) critical thinking skills can be absorbed properly because exceeds the minimum classical completeness limit of $75 \%$. Furthermore, the critical thinking skills of students in every aspect of the control class can be seen in Figure-2 as follows.

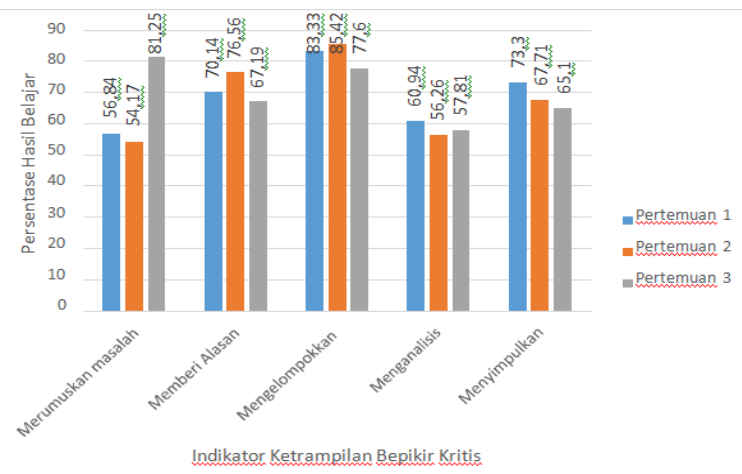

Fig-2: Percentage Diagram of Learning Outcomes for Critica Thinking Skills

Figure-2 shows the value fluctuation in the aspects of formulating problems, providing reasons, classifying, and analyzing. This shows that students have not been trained and used to translating and solving critical thinking problems. The existence of a decrease in learning outcomes in the concluding aspect indicates that the ability of students in the control class in the concluding aspect has not been trained properly. Low learning outcomes occur because the learning used is less able to train students' critical thinking skills. As for the completeness of the learning outcomes of students in the control class has an average value of 61.46 with the classical incomplete category. This shows that the ability to absorb students in the control class is still low in solving critical thinking problems.

The effectiveness of the developed tool can be seen by performing statistical tests of the SPSS program from the learning outcomes data between the experimental class and the control class. First, the data 
normality test was carried out in both classes to determine the data distribution and the results of the data distribution for the two classes were not normal with a sig value. normality $<0.05$. The statistical test was continued with the non-metric test using the Man Whitney Test analysis. The results of the analysis of the Man Whitney Test analysis showed that the data value of Asyrp Sig 2 tiled $<0.05$ (significance below $0.05)$, which means that the experimental class was able to practice critical thinking skills compared to the control class. This is because the use of guided inquiry in the experimental class focuses on thinking processes that build experiences from the active involvement of students in learning.

Kitot et al., [8], in their research stated that there were significant differences between the treatment and control groups. The treatment group showed a higher increase in critical thinking than the control group. Likewise, the research conducted by Sularso (2013) which states that the application of the guided inquiry learning model has a significant effect on the critical thinking skills of students, with the result $\mathrm{P}<\mathrm{a}=0.000<0.05$. The high value in the experimental class is because students learn better when the teaching methodology allows students to be actively involved in class activities, therefore students do not get bored and easily absorb what they learn [9].

\section{CONCLUSION}

Based on the results of the research that has been obtained, it can be concluded that: 1) the learning tools developed are categorized as very valid based on the results of the validation of five experts and the readability of teaching materials and and worksheets by students; 2) The practicality of the learning tools developed is categorized as practical, this can be seen from the activities of students with an average value of $91.75 \%$ in the very practical category and teacher activities with a value of $83.80 \%$ in the practical category; 3 ) The effectiveness of the developed tools is categorized as effective as seen from: a) The completeness of student learning outcomes in the small group test $(90 \%)$ and the experimental class field test $(81.25 \%)$ has exceeded classical completeness $(\geq$ $75 \%)$; b) The average completeness of the indicators of critical thinking skills includes formulating problems, giving reasons, grouping, analyzing and formulating conclusions in the small class group test $(80.41 \%)$ and the experimental class field test $(78.72 \%)$ categorized as effective; 3) The results of the comparison between the experimental class and the control class through the Whitney Test found a significance value below 0.05 indicating that the tool developed and applied to the experimental class was able to train students' critical thinking skills better than the control class.

\section{REFERENCES}

1. Balitbang, P. (2014). Buku Guru Ilmu Pengetahuan Alam. Jakarta: Kementrian Pendidikan dan Kebudayaan.

2. Redhana, I. W. (2003). Meningkatkan Keterampilan Berpikir Kritis Siswa Melalui Pembelajaran Kooperatif Dengan Strategi Pemecahan Masalah. Jurnal Pendidikan Dan Pengajaran.

3. Anam, K. (2015). Pembelajaran Berbasis Inkuiri Metode dan Aplikasi. Yogyakarta: Pustaka Belajar.

4. Sari, N. N. (2018). Pengembangan Perangkat Rencana Pelaksanaan Pembelajaran Materi Rangka, Otot, dan Pesawat Sederhana Jenjang Sekolah Menengah Pertama. Banjarmasin: Tesis Magister Pendidikan IPA.

5. Singh, P., \& Kumar, K. (2015). Effectiveness of Cooperative Learning on Critical Thinking Skills of Secondary School Student. Issues and Ideas in Education, 3(1): 55-62.

6. Ketpichainarong, W., Panijpan, B., \& Ruenwongsa, P. (2010). Enhanced Learning of Biotechnology Students by An Inquiry-based Cellulase Laboratory. International Journal of Environmental \& Science Education, 5(2): 169187.

7. Kang, N., Dechenne, S. E., \& Smith, G. (2012). Inquiry learning of high school Students through a problembased environmental health scinece curriculum. School Science and Mathematic, 112(3): 147-158.

8. Kitot, A. K. A., Ahmad, A. R., \& Seman, A. A. (2010). The Eff ectiveness of Inquiry Teaching in Enhancing Students' Critical Thinking. Procedia Social and Behavioral Sciences 7(C): 264-273.

9. Chebii, R., Samwuel, W., \& Joel, K. (2012). Effects of Science Process Skills Mastery Learning Approach on Students' Acquisition of Selected Chemistry Practical Skills in School. Scientific Research, 3(8):1291-1296. 